\section{Narrativas e imagens dos viajantes alemães no Brasil do século XIX: a construção do imaginário sobre os povos indígenas, a história e a nação*}

\section{The narratives and images of German travelers to nineteenth-century Brazil: the construction of an imagination about indigenous peoples, history, and the nation}

Ana Luisa Fayet Sallas

Professora do Departamento de Ciências Sociais e Programa de Pós-graduação em Sociologia/Universidade Federal do Paraná

Rua General Carneiro, D.Pedro I, 460/9. andar 80060-240 - Curitiba - PR - Brasil analuisa@ufpr.br

Recebido para publicação em novembro de 2009. Aprovado para publicação em março de 2010.
SALLAS, Ana Luisa Fayet. Narrativas e imagens dos viajantes alemães no Brasil do século XIX: a construção do imaginário sobre os povos indígenas, a história e a nação. História, Ciências, Saúde - Manguinhos, Rio de Janeiro, v.17, n.2, abr.-jun. 2010, p.415-435.

Resumo

Analisa relatos e produção iconográfica dos viajantes Wied-Neuwied (18151817), Karl Friedich von Martius (1817-1820) e Johann Moritz Rugendas (1822-1825) com base na construção do imaginário sobre os povos indígenas, a história e a nação. Procura demonstrar as relações entre as ideias/imagens que eles produziram e o debate sobre a natureza do Novo Mundo. Aborda sobretudo a visão de seus empreendimentos como o processo de construção de uma história do Brasil e de sua população, revelando os sentidos e possibilidades existentes para o processo civilizador em curso e o papel que eles desempenharam nesse contexto.

Palavras-chave: viajantes alemães; imagens etnográficas; imaginário da nação; processo civilizador; Brasil.

\section{Abstract}

This analysis of the accounts and iconographic production of German travelers Wied-Neuwied (1815-1817), Karl Friedich von Martius (1817-1820), and Johann Moritz Rugendas (1822-1825) explores the construction of an imagination about indigenous peoples, history, and nation. It shows the relationship between the ideas and images produced by these voyagers and the debate on nature in the New World. Most importantly, it examines their endeavors as a process of constructing a history of Brazil and its people, uncovering the meanings and possibilities relevant to the civilizing process underway and their role in this context.

Keywords: German travelers; ethnographic images; imagination about the nation; civilizing process; Brazil. 
$\mathrm{A}^{\mathrm{s}}$ ideias de nação e história produzidas pelos viajantes europeus que estiveram no Brasil no início do século XIX tiveram papel fundamental na construção de um imaginário sobre os povos indígenas e os modos de inscrevê-los no tempo e no espaço. Esses viajantes chegaram ao Brasil na primeira metade do século XIX buscando conhecer uma parte da América que seu olhar desconhecia, devido aos impedimentos criados pela Coroa portuguesa com relação a seus domínios coloniais no Brasil. Só era permitida a exploração do território a viajantes, cientistas e administradores ligados a Portugal. No entanto, com a vinda da família real para o Brasil, em 1808, esse quadro se alterou consideravelmente. Uma das primeiras providências tomadas pelo rei de Portugal, dom João VI, ao chegar nas terras brasileiras, foi a abertura dos portos a todas as nações amigas de Portugal. $\mathrm{O}$ ato possibilitou o afluxo de vários viajantes europeus que, movidos por objetivos de natureza científica e econômica, buscavam explorar as potencialidades dessa parte da América.

Dentro desse espírito, vieram ao Brasil o príncipe Maximilian Alexander Philip de WiedNeuwied (1815-1817), Karl Friedich von Martius (1817-1820) e Johann Moritz Rugendas (1822-1825), os três envolvidos em empreendimentos de natureza científica e movidos pelo mesmo propósito de descobrir as riquezas e belezas do Novo Mundo. Nosso objetivo é analisar as imagens de natureza, dos povos indígenas e da nação, construídas por esses viajantes. ${ }^{1}$ Para tanto, realizamos um inventário da produção iconográfica de Wied-Neuwied, Martius e Rugendas, em que privilegiamos a sua produção iconográfica publicada nos atlas de Wied-Neuweid e Martius e no álbum Viagem pitoresca, de Rugendas. Num segundo momento, inventariamos o material iconográfico constituído por desenhos e esboços que basearam a produção dessas obras. Um dos desafios iniciais foi justamente a dificuldade de encontrar os originais dos primeiros estudos que orientaram a confecção de litogravuras e gravuras. Foi possível, no entanto, inventariar parte dos desenhos originais e estudos elaborados por Wied-Neuwied e Rugendas.

Assim, o processo de captura das imagens (que ocorre a partir da observação direta do esboço a lápis, do desenho, até a gravação final) sofre modificações pela tradução daquilo que se vê para um código reconhecível, tanto do pintor quanto de seu público. A paisagem observada por Wied-Neuwied, Martius e Rugendas foi submetida a dois crivos de ordem cultural: inicialmente representada pelos viajantes, sofreu em seguida novas alterações quando da passagem do desenho ou aquarela original para a versão final, realizada pelos gravadores. Com relação às obras analisadas, apenas Wied-Neuwied manifestou-se criticamente quanto a esse tipo de ocorrência em seus desenhos. ${ }^{2}$ Sobre esse aspecto vale destacar a observação de Prado (1955, p.329): "O costume de querer melhorar o decorativo das anotações de viagens segundo o gosto do lugar e da época, quando as passavam a estampas, dava-lhes cunho acentuadamente parisiense se feitas na França, suíço se em Basileia na oficina de Steinmann, londrino se na Inglaterra e vienense em Viena". De resto, as obras expressam a conjugação de determinados modelos vigentes à época de sua elaboração e que se cristalizam como expressão de regras a perpassar tanto a elaboração dos desenhos e dos esboços, quanto do quadro acabado e impresso num livro. São produtos de uma determinada cultura, funcionando como guia para as práticas sociais e suas representações. Os desenhos originais, assim, transformaram-se e vieram a público. $\mathrm{O}$ apego às belas paisagens suplantou o interesse pelas especificidades da natureza americana. 
Na perspectiva da produção cultural, cabe ainda destacar que os livros de viagem, com seus atlas e álbuns pitorescos, foram consumidos avidamente pelo público leitor do início do século XIX como bens culturais. Desse modo, o que poderia ser entendido como experiência particular e privada deixa imediatamente de sê-lo ao ingressar no mercado simbólico de bens culturais. Essa relação entre autor e leitor reafirma o caráter público da cultura, que, longe de nos fornecer a verdade da representação, oferece as ideias compartilhadas por determinado grupo acerca da natureza, do homem e da civilização do Novo Mundo. Toda representação contém uma verdade em si, seja ao se destinar a determinados grupos, seja ao expressar crenças e valores de outros. Emerge como expressão da verdade de quem a produziu, como forma de experiência comunicável, inserida no horizonte da época a que está vinculada. Ao analisar essas imagens, portanto, não pretendo buscar o verdadeiro Brasil no início do século XIX, mas sim a maneira como viajantes europeus então o percebiam.

Segundo o historiador Ulpiano T. Bezerra de Meneses (1996), deve-se ter em mente, no uso de fontes iconográficas para a produção do conhecimento histórico, que as imagens são uma forma de suporte de representações. Não é possível pensá-las como mero registro do real externo e objetivo e buscar avaliar seu grau de fidelidade, pois se trata de "uma construção discursiva, que depende de formas históricas de percepção e leitura, das linguagens e técnicas disponíveis, dos conceitos vigentes" (p.152). É necessário, portanto, problematizar o tipo de apreensão que a história pode fazer dos materiais de representação, imagens ou textos, como documentos detentores de uma realidade intrínseca longe da referência imediata a uma verdade, posto que nos dizem algo a respeito de determinado momento histórico porque existem no tempo e no espaço vinculados à experiência de homens concretos.

Meneses (1996) sugere que três aspectos fundamentais devem ser incorporados ao trabalho com imagens. O primeiro é abandonar a falsa polaridade entre real e imaginário, pois a imagem pertence ao real, uma vez que práticas e representações são indissociáveis. O segundo, relacionado à necessidade de a imagem ter valor probatório, é outra falsa questão, pois o valor documental das imagens se refere à problemática das representações sociais, à possibilidade de compreensão do imaginário, e não à capacidade de as imagens confirmarem traços empíricos. Finalmente, ressalta o autor a capacidade de o olhar do viajante instituir um conhecimento sobre a realidade que visita. O autor conclui: "O olhar, portanto, institui seu próprio objeto. A imagem não só é instituída historicamente, como é, também, instituinte. Daí, para um verdadeiro dimensionamento histórico, a necessidade de estudar o circuito da imagem: sua produção, circulação, apropriação, em todas suas variáveis" (p.154; grifo do original). Essas observações metodológicas de Meneses orientaram o processo de leitura e de análise das imagens e das palavras dos viajantes, mas estão, neste artigo, circunscritas à questão das representações de nação, história e povo. ${ }^{3}$

Outro aspecto a destacar é a possibilidade de estabelecer uma tipologia dos viajantes. ${ }^{4}$ Temos em Wied-Neuwied a figura de um viajante naturalista, absolutamente pragmático, atento à observação detalhada e expressão de um espírito relativizador, que busca ponderar o observado em face de outros autores e relatos - seguindo, pode-se dizer, uma perspectiva antropológica. Viajou independente, a serviço apenas do progresso e da ciência.

Naturalista também foi Martius, cujas argutas observações, de caráter antropológico, não deixaram, no entanto, de expressar preconceitos correntes de seu tempo. Viajou a 
Ana Luisa Fayet Sallas

serviço de um rei e foi meticulosamente orientado quanto aos objetivos da viagem e objetos a coletar, para a construção de herbários e museus. Antes de tudo, incorporou a figura do viajante da antiguidade clássica, sem nada a dever aos feitos heróicos de Homero em sua Odisseia. $^{5}$

Rugendas, por sua vez, personifica o artista viajante que exige de seus leitores nem mais nem menos do que a leitura de suas imagens. Engana-se, porém, quem nelas pretende encontrar a expressão de uma realidade objetiva. A trajetória de sua vida e a de suas viagens apresentam etapas distintas na realização de suas aspirações: num primeiro momento, chegou ao Brasil a serviço de uma expedição científica, com roteiros, objetivos e metas claramente estabelecidos por Langsdorff (Expedição Langsdorff..., 1988); em outro, construiu para si a imagem do artista viajante andarilho que buscava retratar com precisão a natureza americana e seus habitantes. ${ }^{6}$

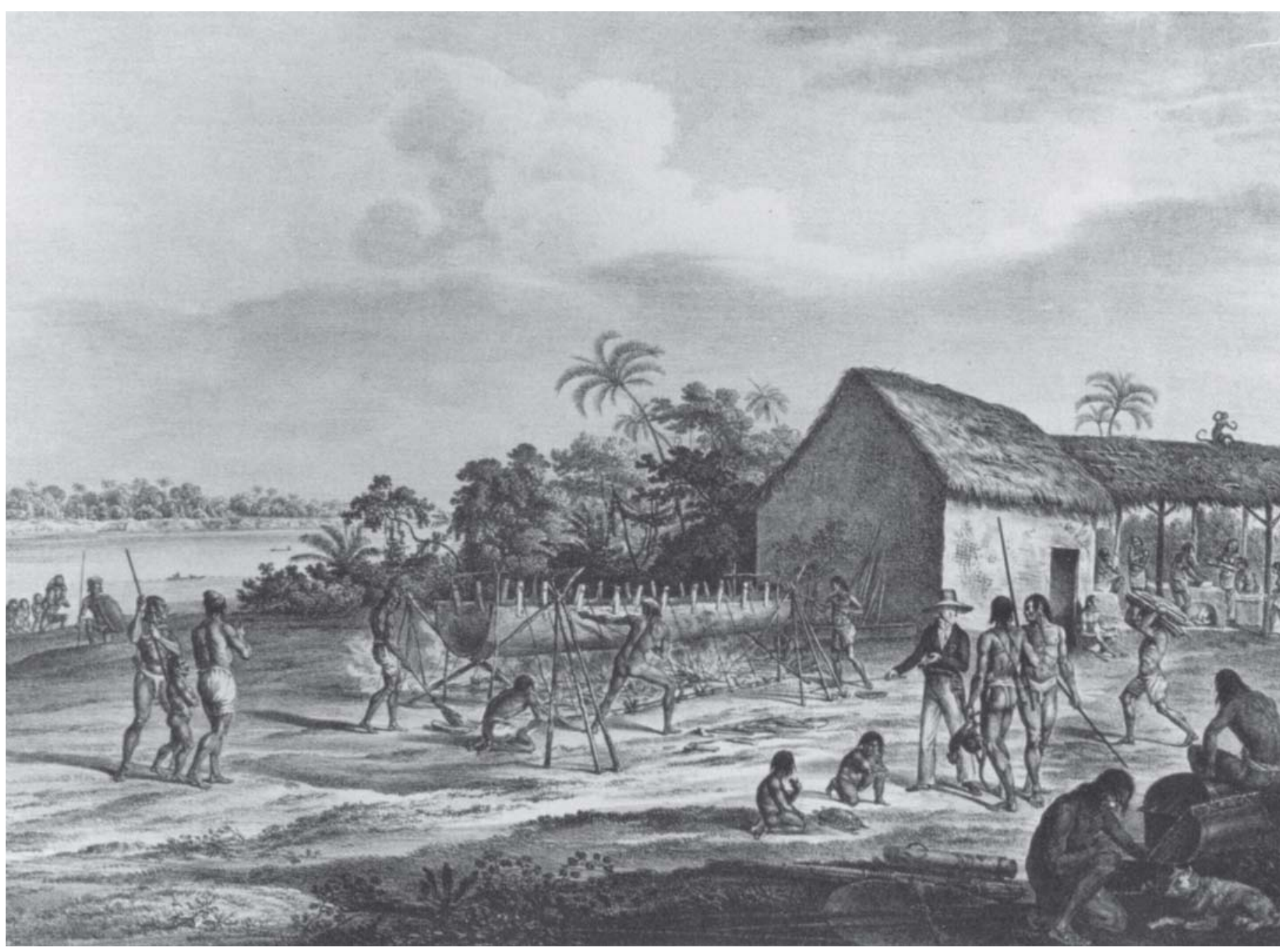

Figura 1: Porto dos Miranha, Martius (Helbig, 1994, p.91) 
A gravura, representando diferentes momentos da viagem, serviu para ordenar a experiência do viajante junto à exuberante natureza e aos povos mais primitivos do Novo Mundo - os Miranha antropófagos. A oportunidade de observar o modo de vida dos diferentes grupos indígenas no Brasil permitiu aos viajantes tecer considerações sobre a origem desses povos, bem como sobre seu grau de cultura e civilização, o que Martius expressou de modo preciso:

Profundamente empolgado pelo arrepio desta solidão selvagem, me sentei para desenhála; mas não tentarei descrever ao leitor os sentimentos que durante este trabalho comoviam minha alma. Era este o ponto mais ocidental a que eu podia estender a viagem. Enquanto me oprimia com todos os terrores de uma solidão destituída de seres humanos, sentia indizível saudade da companhia dos homens da cara Europa civilizada. Pensei como toda a cultura e a salvação da humanidade tinham vindo do Oriente. Dolorosamente comparei aqueles países venturosos com este ermo pavoroso; entretanto, mesmo assim me felicitava por estar aqui, levantei mais um olhar para o céu e volvi corajosamente o espírito e o coração para o Oriente amigo (Spix, Martius, 1981, v.3, p.240).

Essas observações datam da sua chegada à cachoeira de Arara-Coara, acompanhado por 12 índios miranhas e mais duas montarias com soldados do Pará e de Ega. Nesse momento marcante da viagem, o naturalista não encontrou seres humanos com sensibilidade para compartilhar tal feito. Sua imaginação vagava à procura de seus semelhantes, na culta Europa civilizada, pois "toda a cultura e salvação tinham vindo do Oriente". Era necessário marcar aquele momento de assimilação do "ermo pavoroso" à história e à civilização. Só um espírito igualmente sensível e culto poderia entender o gesto do viajante e compartilhar com ele tal felicidade.

As ideias de cultura e civilização foram utilizadas pelos viajantes para compreender as diferenças entre os povos indígenas do Brasil. Ao mesmo tempo, o conhecimento dos povos indígenas constituía um dos objetivos das viagens, pois embasariam os mecanismos de integração desses povos ao Império português. Antes, porém, de apresentar o que esses termos representavam para cada viajante aqui abordado, é preciso compreender o sentido emprestado a eles no século XIX.

Para Norbert Elias (1990), o conceito de civilização minimiza as diferenças nacionais entre os povos por enfatizar aqueles aspectos comuns a toda a humanidade. Vincula-se, no entanto, a um processo de afirmação de povos que já conquistaram suas fronteiras e identidades nacionais e cuja expansão geográfica, bem como a colonização de novas terras, deu-se há muitos séculos. Em contrapartida, o conceito alemão de Kultur procura enfatizar justamente as particularidades nacionais e as diferentes identidades: "Enquanto o conceito de civilização inclui a função de dar expressão a uma tendência continuamente expansionista de grupos colonizadores, o conceito de Kultur reflete a consciência de si mesma de uma nação que teve de buscar constituir incessante e novamente suas fronteiras, tanto no sentido político como espiritual" (p.25). Já o conceito francês de civilisation tinha a função de expressar a autoimagem da classe alta europeia em comparação a outros grupos, fossem eles compostos por pessoas mais simples ou por povos primitivos, servindo também para caracterizar o tipo de comportamento específico pelo qual essa classe se considerava diferente de todas as demais (p.54). Apoiava-se essa autoimagem na ideia de que nela o 
processo de civilização se completara, cabendo-lhe o papel de transmissor, para outras sociedades, da civilização em marcha. Mais do que a autoimagem, a própria consciência da superioridade de sua 'civilização' ante a outras nações não europeias serviu como justificativa para a dominação de outros povos. Nas palavras de Elias, podemos considerar a civilização um processo; a fase fundamental do processo civilizador foi concluída no momento em que houve a consciência de civilização, indicativo de superioridade de seu próprio comportamento e que se materializou na ciência, na tecnologia ou na arte como padrão para todas as nações do Ocidente.

Com base nas ideias expressas por Elias (1990), quanto aos conceitos de cultura e civilização e quanto às distinções entre suas acepções germânica e francesa, vale retomar a ideia de cultura e civilização formulada pelos viajantes, em referência aos povos do Novo Mundo. Na condição de funcionários e artistas originários da classe média, Martius e Rugendas enquadram-se como portadores do conceito de Kultur. No caso do príncipe Wied-Neuwied, embora pertencente à nobreza, ao procurar construir seu itinerário com base em suas realizações intelectuais e científicas como naturalista viajante ele assimilou também esse conceito.

Em outro sentido, esses viajantes alemães, artistas ou naturalistas, encarnaram perfeitamente os ideais da Bildung, uma vez que a própria viagem inscrevia-se como etapa fundamental no processo de formação (no sentido alemão) do jovem cidadão do mundo. $\mathrm{Na}$ realidade, ela fazia parte de um leque de experiências que tendia a dissolver as particularidades nacionais e visava à construção de uma visão de mundo cosmopolita. Como formação, portanto, a viagem era mais importante para a distinção do que a origem social dos viajantes. Por outro lado, ao colocar a questão nesses termos, vale a lembrança de que todos escreveram seus relatos de viagem em francês e alemão a fim de atingir o público letrado desses dois países, além de se terem apresentado em condições de igualdade diante de seus pares das academias de ciências.

Quando os viajantes se referiam ao estado de cultura e civilização dos povos indígenas do Brasil, traziam consigo o sentido germânico do termo Kultur, isto é, uma expressão da sensibilidade. Quanto ao termo civilização, utilizavam-no no sentido francês (civilisation), ou seja, um quadro geral de referência do desenvolvimento da humanidade. É o que podemos constatar em algumas afirmações de Wied-Neuwied (Maximiliano, 1989), quando discorre sobre o estado em que viviam os índios do Brasil. Ao observar o modo de vida dos Botocudo o naturalista associa claramente o desenvolvimento da sensibilidade à ideia de cultura:

Isso condiz exatamente com o caráter dos povos primitivos; está igualmente provado que a sensibilidade dos Botocudo não é tão grande como no-la conta Lafitau, reproduzindo o que ouvira de um missionário brasileiro; nenhum sinal se percebe de tão finos sentimentos. Não se pode efetivamente esperar encontrar na natureza bruta desses homens os sentimentos de delicadeza e de afeto que a cultura e a educação desenvolveram em nós; mas, nem por isso devemos pensar que neles sejam completamente embotados os atributos que distinguem o homem dos irracionais (p.308).

Por outro lado, ao tratar da questão da antropofagia entre os Botocudo, Wied-Neuwied (1989) assinala que em época remota muitas tribos tinham esse "bárbaro costume", 
abandonado progressivamente à medida que firmaram boas relações com os portugueses. Destaca que os próprios índios se haviam convencido do quanto era degradante tal costume, o que, para o viajante, "justifica a esperança de [que] esse povo, cujo estádio de civilização é de todos o mais baixo, [possa] gradualmente progredir para um grau de cultura mais avançado" (p.315). O referido estádio de civilização dos Botocudo deve ser compreendido em relação ao contato daquele povo com os portugueses, isto é, em relação à superioridade da civilização europeia. $\mathrm{O}$ trecho também remete ao sentido de pertencimento dos índios à humanidade: por "grau de cultura mais avançado", é possível considerar justamente aqueles aspectos da vida indígena em seus próprios termos, por elevação da sensibilidade e da modificação dos antigos costumes.

Ao discorrer sobre a origem dos povos indígenas no Brasil, Wied-Neuwied (1989, p.497) destaca a inexistência de referências à pré-história dos povos indígenas, diferentemente das nações dos Tolteca e Asteca: "O investigador interessado em descobrir a origem e a primitiva história dos povos indígenas do Brasil não encontra, como já disse em páginas atrás, nem hieróglifos nem monumentos de qualquer espécie que possam servir para guiarlhe os passos, porquanto, naquelas florestas virgens, o gênero humano ainda não se elevou acima do estado de incultura que por toda parte caracterizou a sua existência primitiva".

Em sua opinião, a única maneira de estudar a origem das sociedades indígenas seria por meio da investigação cuidadosa de seus idiomas, como produtos mais rudimentares da razão humana. Só com o estudo detalhado e comparativo das línguas indígenas seria possível compreender sua origem e história. Essa posição de Wied-Neuwied foi seguida por praticamente todos os viajantes que tentaram construir um quadro o mais fiel possível do

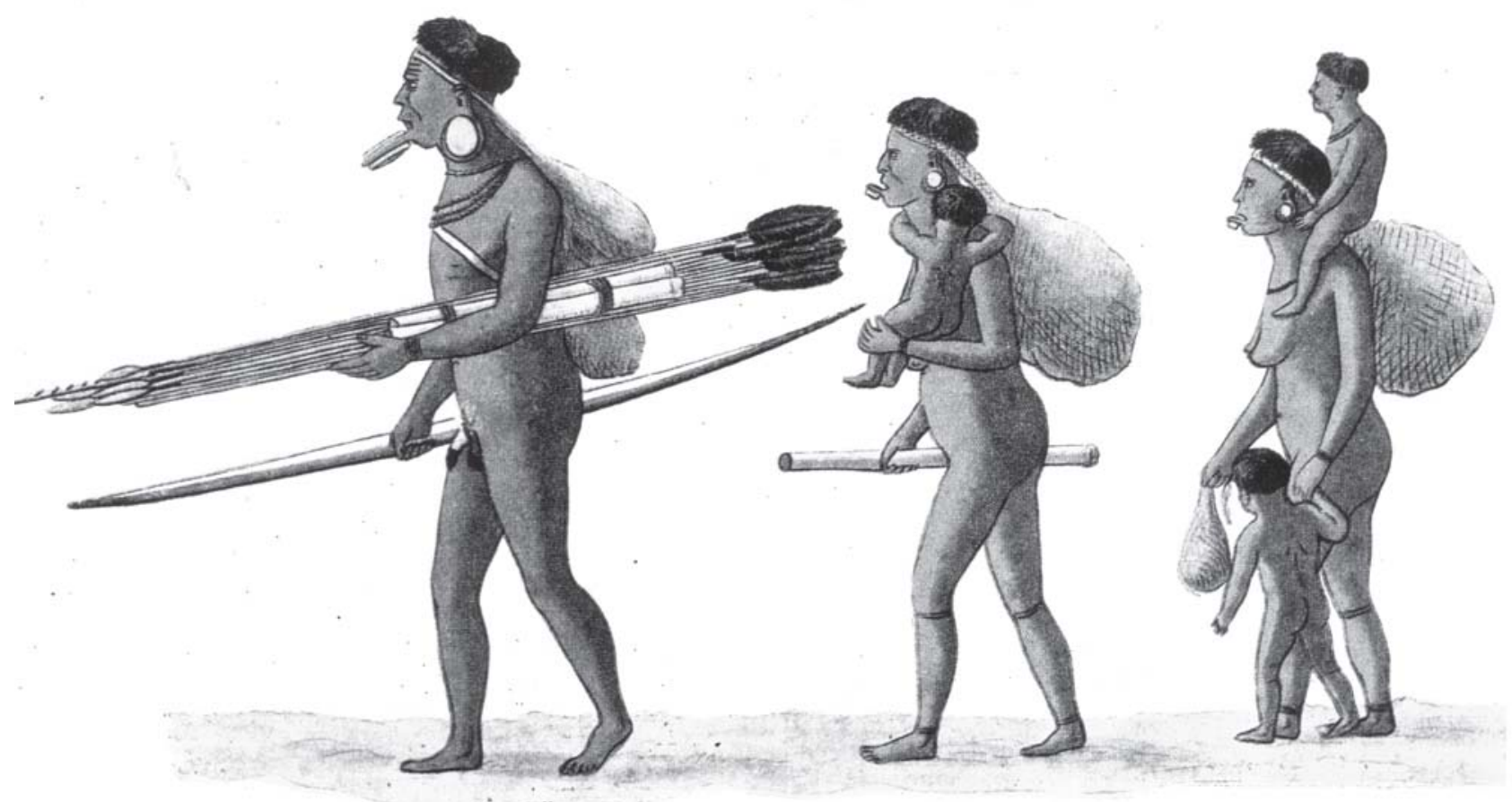

Figura 2: Família de botocudos, Wied-Neuwied (Löschner, 1988) 
Ana Luisa Fayet Sallas

modo de vida dos índios do Brasil. A ideia subjacente era a que os monumentos e a história dos povos primitivos estavam intimamente ligados a sua língua, pois seria através dela que eles poderiam ser reconstruídos. A importância dos estudos das línguas vincula-se de modo decisivo ao pensamento de Johann Gottfried von Herder (1744-1803), que defendia o resgate da tradição histórica e cultural dos diferentes povos com base na análise de suas línguas nativas.

A origem dos povos indígenas, sugere Rugendas (s.d., p.85), explica-se pela ideia de que eles seriam 'restos' de antigas civilizações que decaíram:

Os relatórios dos mais antigos viajantes, como Jean de Léry, Hans Staden etc., demonstram que, na época da conquista, os habitantes primitivos do Brasil estavam num estádio de civilização mais elevado que aquele em que os vemos hoje. A razão principal dessa decadência está, sem dúvida, nas suas relações com os portugueses. Muitos viajantes consideram os povos atuais do Brasil como ainda em estado natural ou como tendo

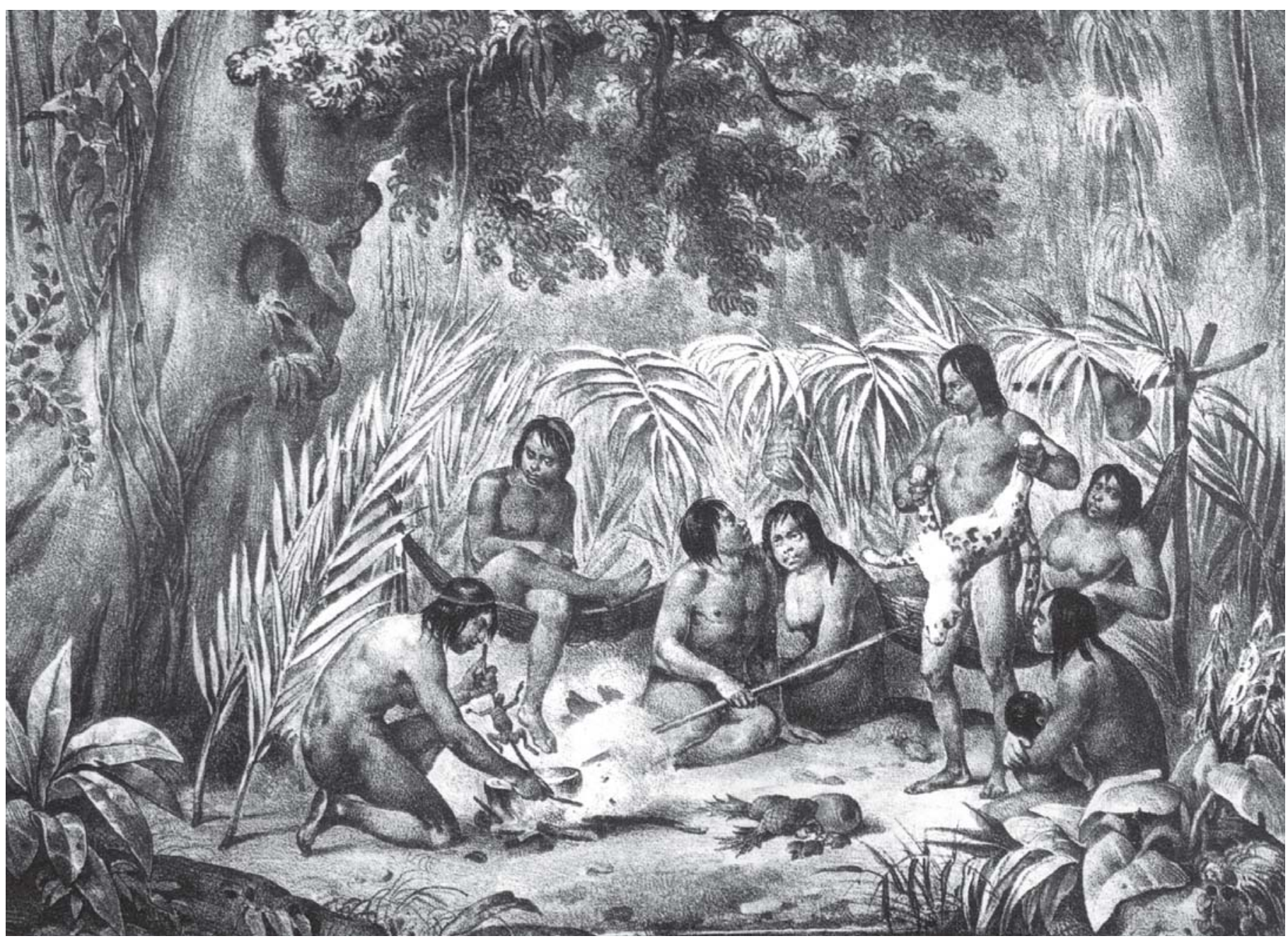

Figura 3: Índios em sua cabana (Rugendas, 1991) 
chegado apenas ao primeiro degrau da civilização. Outros, ao contrário, referem-se aos funestos efeitos da civilização europeia sobre esses selvagens e sustentam que eles são incapazes de assimilá-la. Essas ideias são erradas: os índios não são homens em estado natural e não são selvagens, mas sim homens que retrocederam ao estado de selvageria, porque foram rechaçados violentamente do ponto a que haviam chegado.

Ao destacar que as sociedades indígenas trilhavam o caminho da civilização, mas foram interrompidas nesse processo pelos portugueses, Rugendas colocava-se como crítico do colonialismo: vítimas da política colonial que os submeteu a perseguições, ao trabalho escravo e ao extermínio, os índios "retrocederam ao estado de selvageria". Michèle Duchet (1971, p.223-224) assinala que temas como a colonização e a civilização dos índios caminhavam juntos nos debates dos filósofos no século XVIII; demonstra, no entanto, o quanto esses termos eram irreconciliáveis no contexto do sistema colonial, em que só havia senhores e escravos. Observa que, mesmo sendo assimilados ou incorporados pelos europeus num corpo político artificialmente constituído, os índios não seriam nada além de homens de última categoria - inútil esperar que se os pudesse civilizar ao preço de sua liberdade. Dando à palavra todo o seu sentido - especialmente seu sentido político -, a ideia de civilização, aplicada ao mundo selvagem, termina sempre por destruir-se, pois nada mais é do que disfarce de uma ideia colonial. Os conceitos de Rugendas aproximamse daqueles elaborados por Martius a respeito da origem e do estado dos povos indígenas.

A dança dos índios Coroado de Minas Gerais, foi assistida por Martius e Wied-Neuwied. Era precedida pelo fabrico de uma bebida alcoólica à base de farinha de milho, cozida e posteriormente mastigada pelas mulheres, que devolviam à panela a massa resultante. $\mathrm{O}$ relato de Martius destaca a participação das mulheres nessa atividade. Quando a bebida estava pronta, os índios reuniam-se ao redor da grande panela, após serem chamados para a festa pelo som de uma corneta de chifre.

No meio dos assistentes e próximo da panela, estava de pé o chefe, que, pelo vigor, astúcia e coragem, havia obtido alguma soberania sobre os outros, e tinha recebido de Marlière o título de capitão. Na mão direita, trazia ele o maracá, a castanhola já mencionada, que eles chamam de gringerina, e fazia-a chocalhar, simultaneamente, sapateando ao compasso com o pé direito. Mais caminhando do que dançando, ele movia-se vagaroso, os joelhos curvados e o corpo inclinado para a frente, em volta da panela, para a qual volvia continuamente os olhos. A dança, ao compasso de três tempos, era acompanhada por uma cantiga monótona, em voz baixa, e, quando ele batia com o pé, alteava a voz. Quanto mais repetia a toada, tanto mais solene e apaixonada era a expressão na voz e nas caras. Todos os outros assistentes em volta da panela permaneciam imóveis olhando calados para ele; somente, às vezes, quando as palavras do dançador, que pareciam improvisadas, os incitavam, é que eles prorrompiam em excessiva gritaria (Spix, Martius, 1981, v.1, p.227).

A festa segue um tipo de ordenamento encontrado no teatro, e dela se representam diversas cenas relacionadas entre si. A cena central diz respeito à festa, com a beberagem conduzida pelo chefe, dança e música; ela representa os índios e destaca seus corpos bem torneados, em oposição a suas fisionomias, que são pouco diferenciadas e um tanto apáticas. O chefe indígena que dirige toda a ação tem seu olhar voltado para o lado esquerdo do quadro, onde estão os viajantes, como espectadores. Destaca-se ali a figura do capitão Marlière, paramentado 
Ana Luisa Fayet Sallas

com seu uniforme, em gestual que parece explicar o ritual aos viajantes. Martius está de pé, recostado a uma árvore, e Spix, sentado numa pedra, a seu lado, observa o desenrolar dos acontecimentos festivos daqueles índios. Logo atrás deles, encontra-se um negro carregando uma cesta. Fechando esse lado do quadro, a choça dos índios, que segue o padrão de construção adotado pelos Camacã, ladeada por bananeiras. À esquerda, uma mulher amamenta uma criança; outra, em uma canoa (à direita), representa a posição da aldeia às margens do rio Xitopó, conforme a indicação do viajante. Apresentam-se também vários artefatos indígenas, como lanças, flechas, sacolas e cestarias. O cenário de fundo são as grandes árvores do interior da floresta.

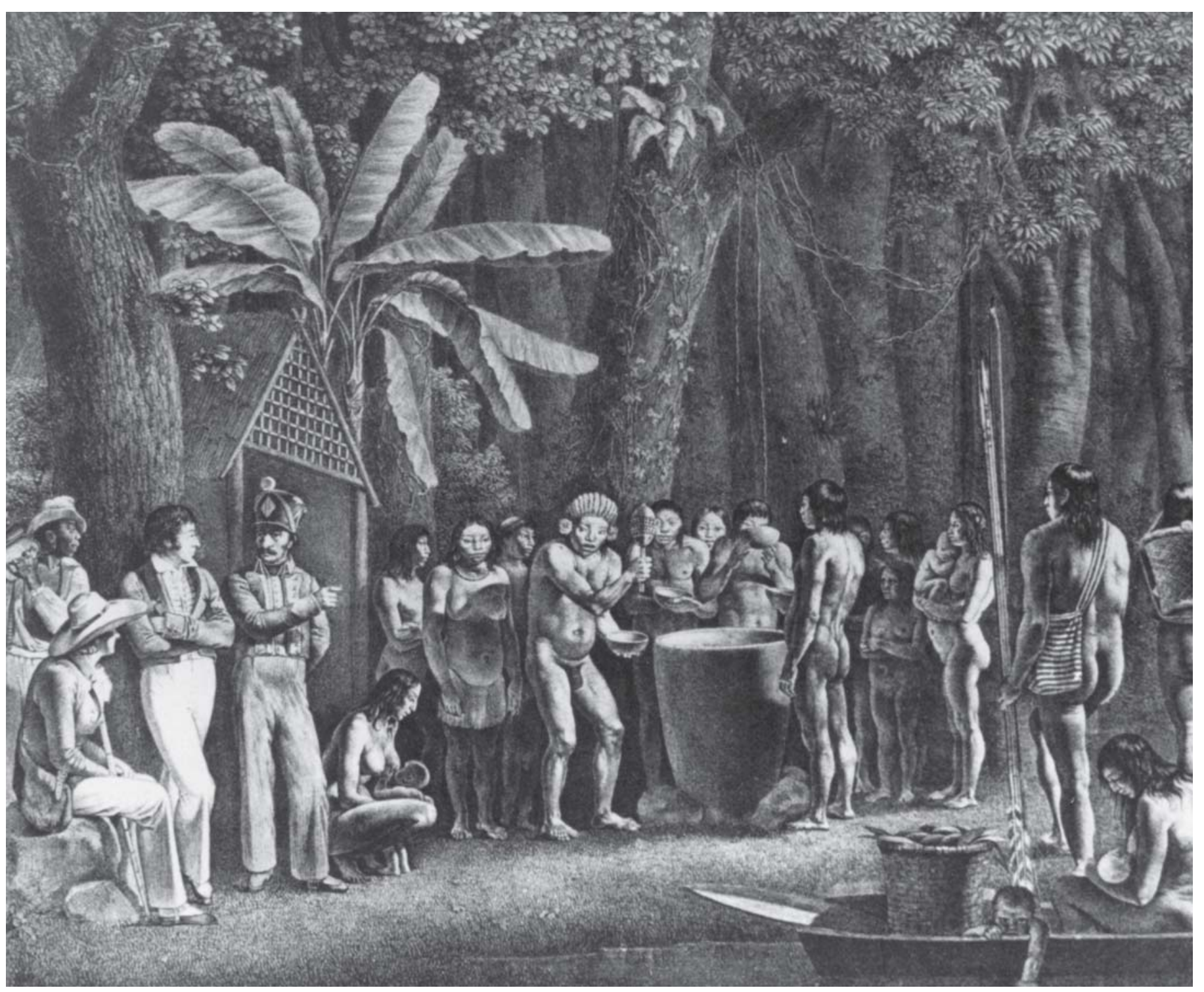

Figura 4: Festa dos Coroado (Helbig, 1994, p.119) 
Esse tipo de figuração revela-se constante em todo o material iconográfico produzido por Martius para seu atlas: sempre que ocorre a representação de alguma cena de vida indígena ou paisagem, os viajantes são colocados na posição de espectadores. Essa autorrepresentação adquire significação posto que concorre para a elaboração de determinada visão dos habitantes do Brasil, de sua natureza e da própria viagem. Um dado de apreensão imediata refere-se ao fato de esse tipo de imagem trazer elementos contrastivos entre a identidade dos índios (pouco diferenciada na gravura) e a dos brancos europeus, que se apresentam vestidos e em posição de destaque. Agregue-se o fato de que, ao presenciar esse tipo de festividade indígena, os viajantes foram levados a elaborar considerações a respeito do estado de civili-

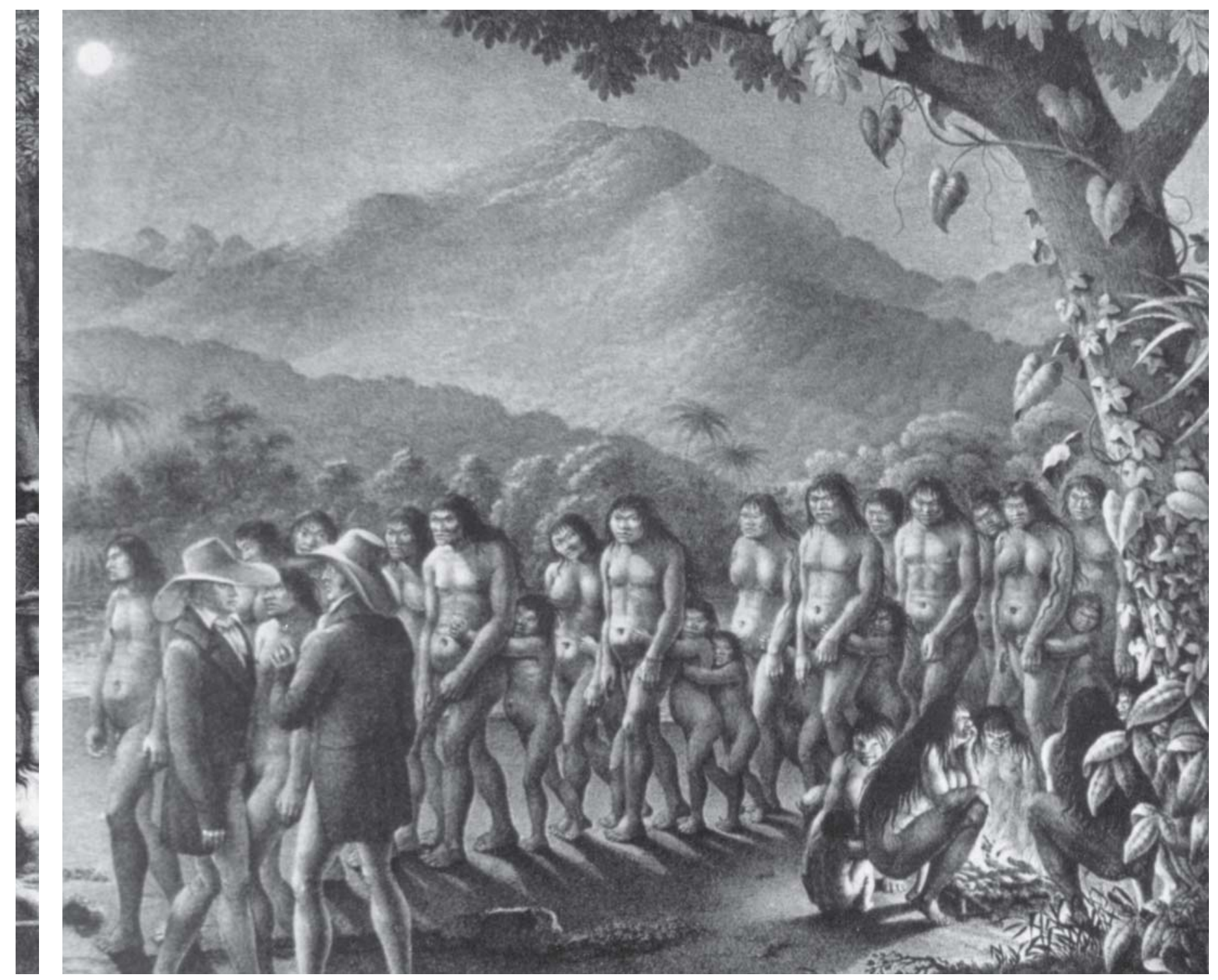

Figura 5: Dança dos índios Puri (Spix, Martius, 1967) 
zação e cultura dos povos com que tiveram contato. A explicação aventada para a conexão entre a observação dos rituais indígenas e as considerações sobre seu estado de civilização e cultura aponta para sua íntima ligação com as práticas de guerra e antropofagia. E de todos os aspectos da vida indígena, nenhum fornecia mais elementos para tal reflexão do que suas festas e danças. Nessa perspectiva, é possível analisar outra gravura do atlas de Martius que segue o mesmo tipo de ordenamento, na representação de uma dança dos índios Puri.

\begin{abstract}
Depois de fartas libações de cachaça, que eles, como todos os índios apreciam apaixonadamente, tornaram-se confiantes e excitados, e executaram as suas danças à noite, num lugar aberto, não distante da Fazenda Cuidoval. Já antes haviam despertado em nós sentimentos melancólicos sobre a degeneração do humano neles, o porte baixinho, o pardo-avermelhado da pele, o cabelo negro de carvão, solto e desgrenhado, o formato desagradável da cara larga, ângulosa, e os olhos pequenos, oblíquos, inconstantes, finalmente o andar de passos curtos, esquivos, desses homens das selvas. E, então, pelo caráter tristonho dessa festa, na escuridão da noite, a nossa impressão de pena ainda era maior. Os homens puseram-se lado a lado em fila; atrás deles puseram-se igualmente em fila as mulheres. Os meninos, aos dois ou três, abraçaram-se aos pais; as meninas agarravamse por trás, às coxas das mães. Nessa atitude, puseram-se eles a cantar o triste 'Han-ja-ha, há-há-há'. Com emoções melancólicas foram repetidas várias vezes a dança e a cantiga, e ambas as fileiras avançavam lentamente, num compasso de três tempos (Spix, Martius, 1981, v.1, p.228).
\end{abstract}

Ainda que a descrição e a imagem da dança dos Puri sigam o tipo de ordenamento já assinalado, nessa gravura tanto os corpos quanto as fisionomias dos índios encontram-se profundamente alterados - aqueles, disformes; estas, igualadas às dos símios -, além de se apresentarem de modo homogêneo. Embora a cena principal seja a dança dos Puri, os elementos em primeiro plano na gravura referem-se à representação dos viajantes, com suas vestes europeias, como espectadores. Existe, na composição dessa gravura alguma inadequação entre o que é narrado, fundamental para a figuração, e a inserção das figuras dos viajantes no centro da cena. Nesse plano destaca-se ainda o aspecto da vegetação local, seguindo o modelo de representação assinalado por Humboldt. ${ }^{7}$ No que seria o plano central da gravura, veem-se, além dos Puri dançando enfileirados, outro grupo de figuras agachadas em torno de uma fogueira. O cenário de fundo da gravura, com florestas densas e montanhas iluminadas pela lua, concorre para a construção desse quadro melancólico aos olhos dos viajantes. Reforçando a ideia de melancolia, Martius informa que um negro que vivera muito tempo entre os Puri revelou-lhe que a música referia-se a um lamento dos índios por terem caído de uma árvore quando tentavam colher uma flor, e conclui: "a explicação que nos ocorria, diante deste quadro melancólico, era do paraíso perdido" (Spix, Martius, 1981, v.1, p.228). Sendo correta essa hipótese, a figura dos viajantes, tal como representada, revela seres estranhos ao paraíso.

A ideia de paraíso perdido era frequente no pensamento europeu quando se buscava explicar a origem dos povos do Novo Mundo. Teve seu auge nos séculos XVI e XVII, quando os debates a respeito daqueles povos eram sobretudo de ordem teológica. Se a ideia do paraíso perdido ainda era expressiva para o entendimento das diferenças, ela aparecia como substrato para a explicação da vida paradisíaca ou da existência de uma cultura adâmica. Os povos que esses viajantes tiveram oportunidade de encontrar eram 
vistos como seres decaídos do paraíso, e suas características físicas e morais corroboravam justamente esse tipo de ideia.

\begin{abstract}
O temperamento do índio quase não se desenvolveu e pode ser qualificado de fleumático. Todas as potências da alma, mesmo a sensualidade mais nobre, parecem achar-se em estado de entorpecimento. Sem refletir sobre a criação universal, sobre as causas e a íntima relação das coisas, vivem com o pensamento preocupado só com a conservação própria. Passado e futuro quase não se distinguem para eles, daí não cuidarem nunca do dia seguinte. Estranhos a todo sentimento de deferência, gratidão, amizade, humildade, ambição, e, em geral, a todas as emoções delicadas e nobres, que distinguem a sociedade humana; insensíveis, taciturnos, imersos no mais absoluto indiferentismo por tudo ... (Spix, Martius, 1981, v.1, p.231).
\end{abstract}

Pelo exposto, evidencia-se o vínculo das ideias de Martius com aquelas expressas por Buffon (1948) quanto aos povos do Novo Mundo, cuja natureza degenerada, apática e de pouca vitalidade concorria para o estado mais baixo de civilização. Há ainda um documento mais significativo elaborado pelo viajante, a dissertação "Como se deve escrever a História do Brasil" ${ }^{\prime}$, de 1843, com o qual participou de concurso promovido pelo Instituto Histórico e Geográfico Brasileiro (IHGB), cujo objetivo era ter um "plano de escrever a história antiga e moderna do Brasil, organizada com tal sistema que nela se compreendam suas partes política, civil, eclesiástica e literária" (Martius, 1845, p.381).

Martius (1845) inicia sua tese com o tópico "Ideias gerais sobre a história do Brasil", em que expõe a necessidade de se conhecerem os elementos humanos que concorriam para o desenvolvimento do homem nos trópicos - elementos de natureza bastante diversa, devido ao fato de representarem a convergência de três 'raças': "a de cor cobre ou americana, a branca ou caucasiana e enfim a preta ou etiópica. Do encontro, da mescla, das relações mútuas e mudanças dessas três 'raças', formou-se a atual população, cuja história por isso mesmo tem um cunho muito particular" (p.390). A relação entre elas produziu, segundo Martius, um movimento histórico específico. Das particularidades físicas e morais de cada uma delas seria possível chegar-se aos elementos que convergiam para o desenvolvimento físico, moral e civil da totalidade da população.

O português é considerado o motor essencial e poderoso do desenvolvimento histórico do Brasil, "como descobridor, conquistador e senhor". Como "raça predominante", atuou sobre os indígenas e os negros, no entanto - Martius (1845) destaca -, para a realização de uma historiografia filosófica do Brasil é fundamental considerar as contribuições das "raças inferiores": "Tanto a história dos povos quanto a dos indivíduos nos mostram que o gênio da história (do mundo), que conduz ao gênero humano por caminhos cuja sabedoria sempre devemos reconhecer, não poucas vezes lança mão de cruzar as raças para alcançar os mais sublimes fins na ordem do mundo" (p.390). Ao enfatizar o papel da 'mescla' de diferentes raças, revela sua visão de história, fundamentalmente providencialista, sendo o "gênio da história" o condutor dos povos e dos indivíduos. Atribui à "vontade da Providência" a mescla de raças no Brasil e ao elemento português a qualidade de um rio poderoso, "a absorver os pequenos confluentes das raças índia e etiópica" (p.390). Essa mescla, segundo ele, teria lugar no seio das classes inferiores, irradiando-se em direção às superiores, posto que estas são historicamente formadas pelos elementos inferiores "e por meio delas se 
vivificam e fortalecem, assim se prepara atualmente na última classe da população brasileira, esta mescla de raças, que daqui a séculos influirá poderosamente sobre as classes elevadas, e lhes comunicará aquela atividade histórica para a qual o Império do Brasil é chamado" (p.390).

Ao atribuir destaque às três raças formadoras da nacionalidade brasileira, Martius acrescenta que espera não estar ferindo a suscetibilidade dos brasileiros. Considera que atribuir o real valor do homem, independentemente de sua cor e seu desenvolvimento anterior, é atributo fundamental do "verdadeiro historiador", que deveria ser portador dessa "filantropia transcendente". No Brasil - observa - tinham sido estabelecidas as condições para o "aperfeiçoamento de três raças humanas", colocadas uma ao lado da outra, sendo que "essa reciprocidade oferece na história da formação da população brasileira em geral o quadro de uma vida orgânica" (Martius, 1845, p.391).

Após expor os princípios gerais para a constituição da história do Brasil, o naturalista pontua as contribuições de cada uma das três raças. Sob o título "Os índios (a raça cor de cobre) e sua história como parte da História do Brasil", aponta a importância de o historiador investigar vida e história do desenvolvimento dos aborígenes americanos lançando-se para um tempo anterior à conquista do Novo Mundo. Pergunta, então: que povos eram aqueles, de onde vieram, quais seriam as causas que "os reduziram a esta dissolução moral e civil, que neles não reconhecemos senão ruínas de povos? ... Só depois de haver estabelecido um juízo certo sobre a natureza primitiva dos autóctonos brasileiros, poder-se-á continuar a mostrar como se formou o seu estado moral e físico por suas relações com os emigrantes" (Martius, 1845, p.392).

Questiona o naturalista as ideias expressas pelos filósofos de que os indígenas foram obra direta da mão do Criador, cuja ação teria como propósito a expressão de alguma razão instintiva, privada de qualquer revelação divina. Considera essa filosofia enganadora pelo fato de os indígenas da América não serem manifestação do estado primitivo do homem. Argumenta que investigações mais aprofundadas provam que não se trata em absoluto do estado primitivo do homem, pois "o triste e penível quadro que nos oferece o atual indígena brasileiro não é senão o resíduo de uma muito antiga, posto que perdida história" (Martius, 1845, p.392). Fato é que, ao chegar ao Brasil, Martius compartilhava as ideias de Rousseau acerca do estado paradisíaco dos povos indígenas. Durante sua estada em meio aos diferentes grupos indígenas, finalmente formulou seu próprio juízo quanto a essas populações, asseverando que elas não passavam de restos degradados de um passado perfeito, que já se encontravam em estado de degeneração muito antes da descoberta pelos europeus.

Em sua tese, assinala ser necessário considerar os indígenas brasileiros em suas manifestações exteriores e, a seguir, compará-los com os povos vizinhos da mesma raça. O passo seguinte seria investigar a extensão de sua atividade espiritual, que se manifesta por "documentos históricos": "Como documento mais geral e mais significativo deve ser considerada a língua dos índios. Pesquisas nesta atualmente tão pouco cultivada esfera não podem jamais ser suficientemente recomendadas, e tanto mais que as línguas americanas não cessam de se achar continuamente em uma certa fusão, de sorte que algumas delas em breve estarão inteiramente extintas" (Martius, 1845, p.393). Observa que a língua principal 
falada pelos índios do Brasil era a "língua geral ou tupi", pertencente a um grande complexo de raças brasileiras. De seu ponto de vista, o fato de ser ela inteligível para um grande número de tribos é prova de ter havido "um único e grande povo, que sem dúvida possuiu a sua história própria, e que de um estado florescente de civilização decaiu para o atual estado de degradação e dissolução" (p.394).

Martius defendia que ao estudo das línguas indígenas deveriam juntar-se os referentes às "mitologias, teogonias e geogonias". A análise dos mitos poderia fornecer elementos relevantes para o conhecimento desses povos, e, nos 'restos' atuais de manifestações de ideias e cerimônias religiosas, seria possível ao "historiador filosófico" encontrar noções anteriores mais puras. Considerava importante, também, a investigação do saber indígena com relação aos fenômenos da natureza. Complementarmente, deveriam ser abordados os vestígios de símbolos e tradições de direito, bem como as relações sociais e jurídicas dos membros de uma tribo com as demais. Apontava, ainda, a necessidade de pesquisas arqueológicas que viabilizassem a descoberta de construções e monumentos reveladores de vestígios das civilizações autóctones existentes no Brasil (Martius, 1845, p.397).

Todo esse programa elaborado por Martius revela as afinidades de suas ideias com as de Buffon quanto à natureza e capacidade dos ameríndios. No entanto, diferentemente do naturalista francês, considerava a natureza tropical um espaço paradisíaco, em que todas as espécies tinham alcançado desenvolvimento pleno, em franca oposição a seus habitantes, seres degenerados, decaídos, "ruínas de antigas civilizações".

Quando o autor trata do elemento indígena, parte do princípio de que ele se encontrava em estado de degeneração, de dissolução moral e civil, "ruínas de povos", resíduos de uma muito antiga e perdida história. Além do sentido romântico nas imagens de ruínas e resíduos de antigas civilizações, identificam-se outros elementos de análise. Essas ideias de Martius foram elaboradas como expressão de um debate que ocorria na Europa desde meados do século XVIII, acerca do estatuto de inferioridade da América e de seus habitantes primitivos, debate esse extensivamente tratado por Antonello Gerbi (1960).

No manuscrito "Bibliotheca brasiliana", elaborado por Martius (1853), encontramos alguns títulos que expressam de modo mais ou menos sistemático as ideias acerca da inferioridade, degeneração ou imaturidade do continente americano, a exemplo das obras de Oviedo (La hystoria general de las Indias, de 1547), Acosta (Historia natural y moral de las Indias, de 1792), Azara (Essais sur l'histoire naturelle des quadrupèdes de la province du Paraguay, de 1801) e Vollneys (Reisen durch die vereinigten Staaten von Nordamerika, de 1804). A expressar mais enfaticamente essas ideias, encontra-se, no catálogo de Martius, a obra de De Pauw, Recherches philosophiques sur les américains ou Mémoires intéressants pour servir à l'histoire de l'espèce humaine, de $1768 .{ }^{9}$

Nada justificava, para Martius, a ideia de que os povos indígenas do Brasil viviam em estado de harmonia com a natureza, ou eram portadores das virtudes idealizadas pelos filósofos europeus. Nesse sentido, as ideias que orientaram sua visão aproximavam-se, em grande medida, daquelas expressas por Buffon e De Pauw. Ao considerar os antigos habitantes do Brasil resíduos de alguma civilização muito antiga, Martius reinterpreta as ideias do século XVIII, de alusão ao dilúvio, à queda dos povos, a um estado de desenvolvimento rumo à degeneração como castigo divino. Segundo Raminelli (1996) essa ideia 
já estava presente no século XVI, quando missionários católicos iniciaram suas atividades de conversão do gentio e trataram de explicar por que os índios representavam um estado de decadência.

É importante destacar as observações finais de Martius (1845), sobre a tarefa cívica e civilizadora do historiador: cívica, porque deveria ser capaz de despertar as virtudes patrióticas de seus leitores; e civilizadora, porque a história deveria ser escrita por um autor verdadeiramente monárquico-constitucional, capaz de traduzir o sentido de unidade da nação que a monarquia buscava representar (p.410). Como se vê, sua visão de história como mestra da vida, a orientar a ação tanto do futuro como do presente, revelava concepções antigas quanto à natureza da história e aos atributos do historiador. A esse respeito, é importante considerar não só as ideias de Martius mas também seu alvo. Bastante esclarecedor para a compreensão dessa questão é o trabalho de Manoel Luís Salgado Guimarães (1988), que analisa a concepção e a maneira como esse projeto foi pensado no IHGB. O autor mostra-nos que essa instituição era portadora de uma concepção dúbia de história: antiga, ao considerar as experiências passadas exemplares para a ação no presente e no futuro; e moderna, ao tentar estabelecer a gênese da nação brasileira. Guimarães afirma: "Utilizando-se categorias próprias da história iluminista, vai-se tentar dar conta da especificidade nacional brasileira em termos da sua identidade e do papel que lhe caberá no conjunto de nações. Projeto não só ideológico, mas também político, está encaminhado pelo IHGB na sua tarefa de contribuir para a construção da nação brasileira" (p.15).

Nesse sentido, é possível compreender a conjunção de interesses expressos pelo IHGB e as ideias de Martius, com relação a como deveria ser escrita a história do Brasil e evidentemente ao projeto de construção nacional. A premiação do naturalista pelo Instituto expressava, mais do que a concordância da instituição com aquelas ideias, a identificação com o referido projeto. Os comentários de Guimarães quanto a essa tese corroboram, em grande medida, as pretensões desse projeto. ${ }^{10}$ Destaca-se ainda o fato de Martius atribuir pouca ênfase ao elemento negro, devido, sobretudo, à consideração de que, na realidade, o escravo negro revelava-se um empecilho à civilização. O elemento branco teria papel de destaque por ser o representante da civilização branca e da própria ciência. Já a história do elemento indígena seria valorizada pela possibilidade de se encontrarem nela os mitos e heróis fundadores da nacionalidade.

As ideias de Martius sobre história foram formuladas do ponto de vista de um naturalista que, em grande medida, tomava como princípio serem as diferenças existentes na formação social brasileira dados naturalizados, não tratados em sua dimensão política e econômica. Por outro lado, sua concepção de história representava uma mudança de interesse verificada pelos naturalistas, a começar por Humboldt. Marie-Nöelle Bourguet (1993, p.35) observa que, no propósito e na função da viagem no início do século XIX, colocava-se explicitamente a questão da história, estabelecendo aproximações entre a geografia e a botânica com a questão da origem da distribuição das espécies. Modifica-se o sentido da história natural - disciplina descritiva e classificatória - para a história da natureza fundada sobre o estudo espaço-temporal de processos geológicos e biológicos. Por meio do espaço geográfico os viajantes naturalistas pensavam a história da natureza e, simultaneamente, a da sociedade e da civilização. Nesse sentido, a análise de esboços, desenhos, aquarelas e gravuras produ- 
zidos pelos viajantes traz a perspectiva de criação de um novo gênero pictórico, que buscava traduzir a experiência de suas viagens como expressão histórica do observado, do vivido. Essas imagens representaram a fusão de determinadas experiências na paisagem. Fixaram o que foram aquelas experiências adquiridas pelos viajantes, que já tinham seus olhares e gestos conformados por uma determinada perspectiva de conhecimento, a da história natural. ${ }^{11}$ Emergia, assim, outro gênero, aqui designado pintura etnográfica, definido em termos da experiência histórica de viajantes e povos observados em fusão com a paisagem tropical.

Consideramos imagens etnográficas aquelas representações dos viajantes que retrataram o modo de vida dos índios em seu habitat natural, sua organização familiar, a construção de suas moradias, sua forma de caçar, cenas guerreiras, suas danças e cerimônias rituais, além de instrumentos guerreiros e artefatos domésticos. De modo geral, todos os viajantes buscaram representar o que observaram e o que julgaram significativo da vida cotidiana dos índios. O resultado dessas observações foi retido em suas narrativas, em desenhos, aquarelas e gravuras, enfatizando a representação da vida indígena nas florestas tropicais. Sob esse aspecto, manifesta-se algo extremamente inovador quanto à representação do homem e da natureza do Novo Mundo. As imagens procuraram retratar o fato observado, e homem e natureza ganharam novo estatuto, já distante de qualquer sentido alegorizante. A busca da precisão científica na representação da natureza precede o princípio da composição das cenas. Quanto ao homem, o tipo de figuração dominante ainda se encontra preso aos cânones acadêmicos; no entanto, em aspectos como o corte de cabelos, a utilização de adornos corporais e tatuagens coloridas é possível apreender a particularidade do grupo representado.

Assim como os viajantes tiveram um modo próprio de encarar a viagem, eles também se distinguiram na descrição e representação dos povos indígenas no Brasil. No geral, demonstraram interesse em associar determinadas práticas da vida indígena a suas ideias a respeito da civilização e da própria história, que, a nosso ver, era reescrita e fixada em suas narrativas, seus desenhos e suas aquarelas, marcando através de seus gestos e da perspectiva da representação, como eram os primitivos habitantes do Brasil. O olhar e a mão se converteram em meios de realizar tal processo.

Os viajantes alemães que percorreram o Brasil no início do século XIX foram representantes da 'civilização em viagem' e encontraram uma natureza exuberante e grandiosa ocupada por seus habitantes primitivos. A história, para eles, traduzia-se por um movimento da civilização à barbárie, proporcionada por seu deslocamento no espaço - era fusão do tempo e espaço como tradução da experiência da viagem. As imagens etnográficas muito revelaram dessa experiência e assinalaram, igualmente, a constituição de um novo gênero pictórico, a pintura etnográfica.

Cada parte do espaço percorrido era percebida como a oportunidade de avanço em direção às formas mais primitivas da vida em sociedade. Reiterando, vale refletir até que ponto essa busca do primitivo, do selvagem não vinha ao encontro de seus ancestrais igualmente primitivos. Martius expressou-a de modo peculiar:

Acerca das viagens realizadas no Japurá antes de mim quase nada sabia eu; mas essa falta de notícias exatas estimulava o meu interesse. O homem está inclinado a colorir as empresas 
que põem a prova a sua coragem com cores dum futuro poético. Ainda me recordo da exaltação com que contemplei a embocadura do majestoso rio, sonhando com o descobrimento de múltiplas maravilhas. Se esses sonhos não se realizaram; devo entretanto ser grato particularmente às experiência que se ofereceram nessa remota região, e que me proporcionavam o aspecto natural, o único exato, do estado primitivo do continente americano e dos seus habitantes (Spix, Martius, 1981, v.3, p.206, v.III).

Conhecer a natureza e o estado primitivo do homem americano apresenta-se ao viajante como possibilidade de estabelecer elos com a antiga história da humanidade. O sentido desse movimento pode ser compreendido pelas afinidades com o pensamento de Friedrich von Schiller (1759-1805) ao discursar, em 1789, sobre a necessidade do estudo da história universal. Conforme destaca Norbert Elias (1997, p.120), Schiller expressava com confiança que, comparando-se o nosso modo de vida com o das sociedades primitivas, a cultura avançara; que muitas sociedades primitivas eram dominadas pela rudeza e crueldade; e que alguns aspectos de sua vida causam repulsa em nossos espíritos. Quanto à glorificação do passado nacional, entretanto, lembrava que não era possível esquecer que César e Tácito haviam encontrado os povos bárbaros do norte da Europa em estado não muito diferente dos povos primitivos de há mil e oitocentos anos. Por isso, recordava a seus contemporâneos que eram devedores de eras passadas e regiões distantes, tendo todos os períodos tão diversos da história da humanidade enriquecido diretamente a 'sua' cultura.

Assim, é possível imaginar que Wied-Neuwied, Martius e Rugendas tivessem reencontrado também, nas sociedades indígenas, a expressão mais fiel daquelas eras primitivas que haviam alimentado seu próprio desenvolvimento histórico e proporcionado o avanço de sua cultura. Esse reencontro possibilitou aos viajantes formular juízos quanto ao estado de civilização daquelas sociedades, inscrevendo-as na história da humanidade, da qual eles seriam a expressão mais perfeita e concluída.

\section{NOTAS}

* Este artigo teve por origem minha tese de doutorado, defendida em 1998 no Programa de Pós-graduação em História da Universidade Federal do Paraná, com o título Ciência do homem e sentimento da natureza: viajantes alemães no Brasil do século XIX. Desde então, foram publicados trabalhos relevantes sobre o tema que abordo, alguns deles aqui referenciados ainda como manuscritos a que tive acesso durante a realização da minha pesquisa, como o de Marie Nöelle Bourget (1993). Nessa condição estão também os trabalhos de Robert Slenes, 1995 e M. Fátima Costa e Pablo Diner, 1995a, 1995b e 1993.

${ }^{1}$ É muito extensa a bibliografia produzida, no Brasil e fora dele, sobre a importância que as imagens e palavras (narrativas) dos viajantes estrangeiros tiveram sobre a constituição das imagens do Brasil e de um imaginário que alimentou o processo de construção do país em sua identidade nacional. Ver, entre outros, Carneiro, 1976; Cascudo, 1977; Chiappelli, 1972; Cunha, 1986; Löschner, 1978; Richert, 1959; Röder, 1969; Sampaio, Teschauer, 1955; e Slenes, 1995.

${ }^{2}$ Assim Wied-Neuwied se manifestou: "A gravação das chapas foi feita por gravadores especializados; não obstante todos os esforços introduziram-se assim mesmo algumas inexatidões" (citado em Löschner, 1978, p.108; e Röder, 1969).

${ }^{3}$ Dados os limites do artigo, não serão abordadas a questão da paisagem nem os aspectos relativos às imagens etnográficas, que traduziram, em grande medida, o que foi o sentido da experiência da viagem para esses alemães.

${ }^{4}$ Trabalhos fundamentais de análise da produção iconográfica dos viajantes estrangeiros no Brasil para o conhecimento dos povos indígenas são os de Schaden, 1955, Triborn, 1955 e Hartmann, 1975. 
${ }^{5}$ Sobre esse aspecto do sentido da experiência da viagem de Martius e Spix, ver Lisboa, 1997.

${ }^{6}$ Sobre a expedição de Langsdorff e a trajetória de Rugendas há extensa bibliografia. Ver, entre outros, Costa, Diener, 1995a, 1995b e 1993; sobre Rugendas, ver Diener, 1992 e 1994.

${ }^{7}$ A importância de Humboldt na conformação de uma perspectiva modelar de visão da América Latina foi assinalada por diversos autores. Entre os mais importantes está Löschner (1988, 1976); sobre as implicações políticas dessa visão de Humboldt, ver Pratt, 1991 e 1992.

${ }^{8}$ A tese de Martius foi apresentada ao IHGB sob a forma de manuscrito, em alemão, e premiada com uma medalha de ouro em 1847. Foi traduzida pelo barão de Capanema e publicada na Revista do Instituto (tomo 6, de 1845). Acompanhando a tese, Martius enviou sua "Bibliotheca brasiliana", com um "catálogo das publicações referentes à história do Brasil", desde o descobrimento até 1842. Esse catálogo, um manuscrito com 52 folhas, tem sua introdução escrita em português. A organização da bibliografia dáse em ordem cronológica, iniciando com a Epistola histofori Columbi, de 1493, e terminando com as Recherches historiques, critiques et bibliographiques sur Americ Vespucie et ces voyages, por M. Visconde de Santaren, de 1842. A "Bibliotheca brasiliana" encontra-se atualmente na Biblioteca do Instituto. Desconheço a sua publicação integral. Algumas obras referenciadas por Martius foram por ele doadas ao IGHB e fazem parte do acervo da instituição. A relação delas foi publicada na Revista do Instituto Histórico e Geográfico (tomo 83, 1919). Sob o título Arquivo do Instituto, constam os manuscritos de Martius, a relação das obras doadas ao Instituto e a relação dos livros que pertenceram à biblioteca de Martius e que contém seu ex-libris.

${ }^{9}$ Todos esses autores foram tratados com profundidade por Antonello Gerbi (1960), ao discorrer sobre o tema da degeneração e imaturidade do continente americano. Segundo Lisboa (1997), mais do que com Buffon, era com Cornelius De Pauw (1739-1799) que Martius compartilhava ideias. Para esse etnólogo, a degeneração natural dos índios não seria um processo, mas sim um estado original do qual jamais esses grupos saíram, correspondendo, desse modo, ao inverso da civilização. Essa ideia era reforçada pela ausência de vestígios do passado dos povos indígenas - portanto, seu passado seria igual a seu presente.

${ }^{10}$ Guimarães (2000) aprofunda a análise sobre a concepção de história em von Martius estabelecendo algumas conexões mais significativas sobre a experiência da viagem, o olhar do viajante e o vínculo entre o ver e o saber então construído. Em grande medida, seus argumentos e referências associam-se com o que foi abordado em minha tese de doutorado em 1998, em que trato amplamente dessas questões, com foco especial sobre a visão da natureza e sua relação com a paisagem (descrita e desenhada), como também com os povos indígenas, relação esta fixada em suas imagens etnográficas como aquelas que analiso neste artigo.

${ }^{11}$ Preciosa fonte documental sobre essas orientações é o trabalho de Delegrave (1877), com suas instruções sobre o que observar e como coletar e registrar as experiências de viagem ao redor do mundo.

\section{REFERÊNCIAS}

BOURGUET, Marie-Nöelle.

Voyage, statistique, histoire naturelle: l'inventaire du mondu au siècle des Lumières. Campinas: Université de Campinas /Université Paris: VII/ Denis-Diderot. (mimeo.). 1993.

BUFFON, Georg.

Pages choises: classiques Larouse. Paris: Librairie Larousse. 1948.

CARNEIRO, Newton.

Rugendas no Brasil. Rio de Janeiro: Livraria Kosmos Editora. 1976.

CASCUDO, Luis da Camara.

O príncipe Maximiliano de Wied-Neuwied no Brasil, 1817-1818. Rio de Janeiro: Livraria Kosmos. 1977.

CHIAPPELLI, Fredi (Ed.).

First images of America: the impact of the New
World on the Old. Berkeley: University of California Press. 2v. 1972.

COSTA, Maria de Fátima; DIENER, Pablo (Org.).

O Brasil de hoje no espelho do século XIX: artistas alemães e brasileiros refazem a Expedição Langsdorff. São Paulo: Estação Liberdade. 1995a.

COSTA, Maria de Fátima; DIENER, Pablo (Org.).

Viajando nos bastidores: documentos de viagem da Expedição Langsdorff. Cuiabá: Editora UFMT. 1995b.

COSTA, Maria de Fátima; DIENER, Pablo (Org.). Percorrendo manuscritos: entre Langsdorff e D'Alincourt. Cuiabá: Editora Universitária. 1993. 
CUNHA, Euclides da.

Um paraíso perdido: ensaios, estudos e pronunciamentos sobre a Amazônia. Rio de Janeiro: José Olympio. (Coleção Documentos Brasileiros). 1986.

DELEGRAVE, Charles (Ed).

Le tour du monde en trois cent vigt jours complément d'instruction expériense: institution approuveé par les Societés de Géographie de Paris et de Londres ... voyage d'instruction et d'agrément organizés par la Société des Voyages d'Etudes Autour du Monde. Paris: Editeurs de la Societé de Géographie de Paris. 1877.

DIENER, Pablo O. (Org.).

Rugendas: imágenes de México - exposición Museo Nacional de Historia. México D.F.: Augsburb, Bernd Wibner. 1994.

DIENER, Pablo O. (Org.).

Rugendas: America de punta a cabo - Rugendas y la Araucanía. Chile: Editorial Aleja. 1992.

DUCHET, Michèle.

Anthropologie et histoire au siècle des lumières. Paris: François Maspero. 1971.

ELIAS, Norbert.

O processo civilizador: uma história dos costumes. Rio de Janeiro: Jorge Zahar. 1990.

\section{EXPEDIÇÃO LANGSDORFF...}

Expedição Langsdorff ao Brasil, 1821-1829. Iconografia do Arquivo da Academia de Ciências da União Soviética. Reprodução fotográfica, Claus C. Meyer; texto, Boris Komissarov. 3v. Ilustrações: v.1, Rugendas, desenhos e aquarelas (83 ilust.); v.2, Taunay, desenhos e aquarelas (165 ilust.); v.3, Florence, desenhos e aquarelas (146 ilust.). Rio de Janeiro: Edições Alumbramento. 1988.

GERBI, Antonello. La disputa del Nuevo Mundo: história de una polémica, 1750-1900. México: Fondo de Cultura Económica. 1960.

GUIMARÃES, Manoel Luís Salgado. História e natureza em von Martius: esquadrinhando o Brasil para construir a nação. História, Ciências, Saúde - Manguinhos, Rio de Janeiro, v.7, n.2, p.391-413. 2000.

GUIMARÃES, Manoel Luís Salgado. Nação e civilização nos trópicos: o Instituto Histórico e Geográfico Brasileiro e o projeto de uma história nacional. Estudos Históricos, Rio de Janeiro, n.1, p.5-27. 1988.

HARTMANN, Thekla.

A contribuição da iconografia para o conhecimento de índios brasileiros do século XIX. São Paulo: Coleção Museu Paulista. (Série de Etnologia, 1). 1975.
HELBIG, Jörg (Hg.).

Brasilianische Reise 1817-1820: Carl Friedrich Philipp von Martius zum 200. Geburtstag.

München: Hirmer. 1994.

LISBOA, Karen Macknow.

A nova Atlântida de Spix e Martius: natureza e civilização na 'Viagem pelo Brasil (1817-1820)'. São Paulo: Hucitec. 1997.

LÖSCHNER, Renate.

Alexander von Humboldt: inspirador de la nueva ilustrácion de América - Artistas y científicos alemanes em Sudamérica y México. Exposición del Instituto Ibero-Americano, Patrimonio Cultural Prussiano. Berlin: GmbH \& CO.KG. 1988a.

LÖSCHNER, Renate.

Brasilien Bibliothek der Robert Bosch GMBH:

Maximilian Prinz zu Wied. Katalog. Stuttugart: Deutsche Verlags-Anstalt. 1988b.

LÖSCHNER, Renate.

Artistas alemães na América Latina: catálogo da exposição. Berlim: Instituto Ibero Americano. 1978.

LÖSCHNER, Renate.

Lateinamerikanishe Landschaftsdarstellungen der maler aus dem unkreis von Alexander on Humbolt. Inaugural dissertation. Berlin. 1976.

MARTIUS, Carl Friedich Philipe von. Bibliotheca brasiliana: catálogo das publicações referentes à história do Brasil desde o descobrimento da América até o ano de 1842. Munique, 20 de janeiro de 1853. Manuscrito. (Instituto Histórico e Geográfico Brasileiro). 1853.

MARTIUS, Carl Friedich Philipe von. Como se deve escrever a história do Brasil. Revista do Instituto Histórico e Geográfico Brasileiro, Rio de Janeiro, t.6, n.24, p.381-403. 1845.

MAXIMILIANO, Príncipe de Wied-Neuwied. Viagem ao Brasil. Belo Horizonte: Itatiaia. (Coleção Reconquista do Brasil, 2. série, v.156). 1989.

MENEZES, Ulpiano T. Bezerra.

Morforlogia das cidades brasileiras: introdução ao estudo histórico da iconografia urbana. Revista USP, São Paulo, n.30, p.144-155. 1996.

PRADO, João Francisco de Almeida. Thomas Ender: pintor austríaco na corte de dom João VI no Rio de Janeiro - um episódio da formação da classe dirigente brasileira, 1817/ 1818. São Paulo: Companhia Editora Nacional. 1955. 
PRATT, Mary Louise.

Imperial eyes and transculturation. London: Routledge. 1992.

PRATT, Mary Louise.

Humboldt e a reinvenção da América. Estudos Históricos, Rio de Janeiro, v.4, n.8, p.151-165. 1991.

RAMINELLI, Ronald.

Imagens da colonização: a representação do índio de Caminha a Vieira. Rio de Janeiro: Jorge Zahar. 1996.

RICHERT, Gertrud.

Johann Moritz Rugendas, ein Deutscher maler des XIX. Berlin: Rembrand. 1959.

RÖDER, Joseph.

Maximilian Alexander Philipp, príncipe de Wied: viagem ao Brasil 1815-1817 - excertos e ilustrações. São Paulo: Melhoramentos. 1969.

RUGENDAS, Johann Moritz.

O Brasil de Rugendas. Belo Horizonte: Vila Rica Editoras Reunidas. (Coleção Imagens do Brasil, 1). 1991.

RUGENDAS, Johann Moritz.

Viagem pitoresca através do Brasil. São Paulo: Círculo do Livro. s.d.

SAMPAIO, Theodoro; TESCHAUER, Carlos. Os naturalistas viajantes dos séculos XVIII e XIX e a etnografia indígena. Salvador: Livraria Progresso Editora. 1955.

SCHADEN, Egon.

[Resenha]. Josef Röder und Hermann Trimborn: Maximilian Prinz zu Wied - Unveröffentlichte
Bilder und Handschriften zur Völkerkunde Brasiliens. Bonn: Ferd. Dümmlers. 1954. in $8^{\circ}$, 16 figuras em pranchas fora do texto, bibliografias, anexo um álbum com 42 reproduções de aquarelas. Revista de Antropologia, São Paulo, v.3, n.1. 1955.

SLENES, Robert W.

Bávaros e Bakongo na 'Habitação de negros': Johann Moritz Rugendas e a invenção do povo brasileiro. Mimeo. 1995.

SPIX, Johann Baptist von; MARTIUS, Karl Friedrich Philipp von.

Viagem pelo Brasil: 1817-1820. 3v. São Paulo: Editora da Universidade de São Paulo. 1981.

SPIX, Johann Baptist von; MARTIUS, Carl Friedrich Philipp von.

Reise in Brasilein, in den Jahren 1817-1820.

Neudruch des 1821-1832 in München in 3

Textbänden und 1 Tafelband erschienenen

Werkes, herausgegeben und un ein Lebensbild des Botanikers von Martius sowie einers Registers erweitert von Karl Mägderfrau Tafelband. Stuttgart: F.A. Brockhaus Komm. 1967.

TRIBORN, Herman.

Acuarelas y dibujos inéditos del príncipe Maximiliano de Wied, referentes a la etnografia del Brasil. In: Congresso Internacional de Americanistas, 31, São Paulo. Anais... São Paulo: Editorial Anhembi. p.245-250. 1955. 